\title{
Corrosion of Galvanized Steel Under Different Soil Moisture Contents
}

\author{
Roseana Florentino da Costa Pereira ${ }^{a *}$, Edkarlla Sousa Dantas de Oliveira ${ }^{\text {, }}$ \\ Maria Alice Gomes de Andrade Lima ${ }^{b}$, Simone Louise Delarue Cezar Brasil
}

\author{
${ }^{a}$ Departamento de Engenharia Mecânica, Universidade Federal de Pernambuco - UFPE, \\ Avenida da Arquitetura, s/n, Cidade Universitária, CEP 50740-550, Recife, PE, Brazil \\ ${ }^{b}$ Departamento de Engenharia Química, Universidade Federal de Pernambuco - UFPE, \\ Avenida Professor Artur de Sá, s/n, Cidade Universitária, CEP 50740-521, Recife, PE, Brazil \\ ${ }^{c}$ Departamento de Processos Inorgânicos - DPI, Universidade Federal do Rio de Janeiro - UFRJ, \\ Avenida Athos de Silveira Ramos, 149, Bloco E, Cidade Universiária, Ilha do Fundão, \\ CEP 21945-970, Rio de Janeiro, RJ, Brazil
}

Received: October 24, 2014; Revised: April 28, 2015

\begin{abstract}
Galvanized steel has been widely applied in different applications and the industry significantly increased its production in recent years. Some galvanized structures can be completely or partially buried, such as transmission tower footings. The corrosion of these metallic structures is related to the soil chemical and physicochemical properties, which define the aggressiveness of the environment. To assess the effect of the soil moisture on galvanized steel corrosion, a comparative study was carried out. Carbon steel coupons, with or without galvanization, were buried in clay soil collected from an industrial region in the northeast of Brazil. The chemical, physicochemical and microbiological characteristics of the soil were determined. The thickness of the galvanized coating was measured by scanning electron microscopy (SEM). Corrosion tests were conducted in different soil moisture conditions using the following techniques: potentiodynamic polarization curves and gravimetric tests. The results showed the influence of soil moisture on corrosion rates. The electroplating decreased corrosion rates, especially when the coupons were exposed to low moisture soil.
\end{abstract}

Keywords: corrosion, galvanized steel, potentiodynamic polarization, soil

\section{Introduction}

Hot dip galvanizing process promotes steel and cast iron corrosion protection. The steel structure is immersed in a molten zinc bath, that reacts with the steel producing a tightly bonded coating, isolating the metal surface from the environment and promoting cathodic protection ${ }^{1,2}$. In case of coating damage, zinc oxidation products, which are adherent and insoluble, are deposited on the surface, keeping it protected ${ }^{3}$.

Galvanizing has been increasingly applied because of zinc protective characteristic that, associated to the steel mechanical strength, results in a versatile and economic product. Galvanized products find many applications in transmission towers, telecommunication equipment, agricultural product stores, road safety, civil construction and pipes ${ }^{1,2}$. Usually, those structures are partially or completely buried and their corrosion resistance depends on the aggressiveness of soil. The resistance to corrosion processes of buried galvanized structures is related to chemical, physicochemical and microbiologic properties of the soil ${ }^{3,4}$.

The evaluation of soil corrosiveness is important to analyze corrosion processes of underground structures and to define protective methods, such as cathodic protection or protective coatings. Among the main factors that influence soil corrosiveness, electric resistivity can be highlighted. This

*e-mail: roseana94@gmail.com physicochemical property indicates the capacity of electric currents to flow between anodic and cathodic areas and, consequently, to promote corrosion of metallic surfaces ${ }^{2,4}$. Other parameters, such as presence of salts, $\mathrm{pH}$, moisture, redox potential and concentration of sulfate-reducing bacteria (SRB) are taken into account in the evaluation of soil corrosiveness through some criteria, such as Steinrath or modified Steinrath Indexes ${ }^{4,5}$.

The objective of this work is to assess the effect of hot dip galvanizing in buried structures, through a comparative study between carbon steel with or without galvanization under different soil moisture contents.

\section{Methodology}

\subsection{Coupons}

AISI 1020 carbon steel coupons $(25.5 \times 25.5 \times 6.3) \mathrm{mm}$ were used in experimental tests. For comparison, half the coupons were hot dip galvanized ${ }^{6}$ and the other half was blasted with glass microbeads. The blasting was applied to standardize the surface, eliminating areas of preferential corrosion, sharp edges, scratches, oxidation products and other heterogeneities that may enhance corrosion processes. The coupons were immersed in isopropyl alcohol and acetone, dried and weighed. To promote electric contact 
for electrochemical tests, threaded metal rods were welded to the coupons.

After the immersion test, galvanized coupons were cut in cross section and prepared for metallographic examination. Mechanical polishing was carried out with water-free lubrificant to avoid further corrosion. Etching was carried out with 0.5 vol $\%$ Nital to reveal the coating microstructure. Galvanizing layers were observed by SEM (scanning electron microscopy) using a Hitachi TM 3000 scanning electron microscope.

\subsection{Soil}

The clay soil sample used in this experimental work was collected in Pernambuco, Northeast of Brazil, near transmission towers of a thermoelectric plant. Chemical, physicochemical and microbiologic soil parameters were determined.

Sulfate and chloride were determined according to the methodology described in $\operatorname{Vogel}^{7}$ and sulfide content according to an adaptation of the colorimetric method using N.N-dimethyl-p-phenylene diamine ${ }^{8}$.

Resistivity measurements carried out in laboratory, in samples as received, are not usually considered representative of in situ conditions and climatic variations. Thus, a specific test was conducted, which consider the relation between resistivity and moisture content. The experimental device used in this tests comprises a soil box and a resistivity meter, following technical recommendation ${ }^{8}$. The resistivity is measure while water is added to the soil in specific amounts.

Soil redox potential was determined using a platinum counter-electrode and copper-copper sulfate $\left(\mathrm{Cu} / \mathrm{CuSO}_{4}\right)$ reference electrode ${ }^{9}$. Soil $\mathrm{pH}$ was determined by potentiometric method in soil suspension in distilled water $(1: 2.5)^{[10]}$. For SRB quantification, a soil sample was dissolved in reducing solution and distributed in modified Postgate E medium ${ }^{11}$, with the MPN technique, incubated for 28 days.

In addition, with the results of the above analyses, soil corrosiveness was evaluated by Steinrath and modified Steinrath Indexes 5 .

\subsection{Experimental tests}

The 60-day test was carried out in a 120 L plastic container fulfilled of soil. Test coupons were placed in this container in two depth levels separated by $60 \mathrm{~cm}$, where the deepest level corresponds to the high moisture soil (HM) and less deep level, the low moisture soil (LM). This condition is possible due to the water retention capacity and the textural characteristics that influence the moisture content.

An appropriated equipment for soil moisture measurement (FALKER HFM 2010) was used. The sensors were installed at the same depth where the coupons were immersed, in order to monitor soil moisture (HM and LM) during the test.

In order to determine corrosion rates by gravimetric analyses, the coupons were removed at different periods over the 60 day-test, shaved and cleaning by chemical stripping procedure according the standard ${ }^{12}$. Corrosion rates can be classified according different standards. In this work, NACE RP-077514 ${ }^{[13]}$ classification is considered.

The corrosion potential of coupons at different depth levels was daily monitored using a $\mathrm{Cu} / \mathrm{CuSO}_{4}$ reference electrode.
Potentiodynamic polarization curves (potencial vs current density) were obtained in anodic and cathodic ranges at $0.1 \mathrm{mV} / \mathrm{min}$ scanning rate. A three-electrode cell was used: steel or galvanized steel coupon (working electrode), $\mathrm{Cu} / \mathrm{CuSO}_{4}$ reference electrode and Ti-MMO (Mixed Metal Oxides) as a counter electrode. The tests were carried out using an AUTOLAB Galvanostat/Potentiostat, controlled by NOVA 1.7 program. The curves were obtained in soil with different moisture content and the results were analyzed according to current standards ${ }^{14}$.

The aim of this test was to determine the corrosion rate expected and to evaluate protective characteristics of corrosion produtcs. Potentiodynamic polarization, besides being a technique that analyzes the corrosion as an electrochemical phenomenon, has great reliability and does not require long periods.

\section{Results and Discussion}

Figure 1 shows the zinc coating microstructure applied to steel coupons. The immersion of steel substrates in liquid zinc bath, promotes several reactions depending on the bath composition and the steel, forming primary phases during long-time immersion galvanizing: eta, zeta (1 and 2), delta and gamma ${ }^{15,16}$. The gamma phase is thin, growing with the immersion time. The morphology of the zeta crystallites is coherent and columnar, and the delta phase is relative compact, with fewer cracks.

The Brazilian standard NBR $6323^{[17]}$ recommends $74 \mu \mathrm{m}$ as a minimum thickness for hot dip galvanized coating. However, in this work, the galvanized coating thickness shows an average value of $62 \pm 5 \mu \mathrm{m}$, lower than the Brazilian standard requirements. Despite this, the microstructure of the galvanized coating can be adequate, with an outer protective pure zinc eta layer well defined and representing at least $45 \%$ of the thickness of the coating ${ }^{16}$. This condition is necessary to consider the coating efficient to cathodically protect the steel against corrosion.

Figure 2 shows the profile of electric resistivity $v s$ moisture content, as well the experimental device: resistivity meter and soil box. Soil resistivity measurement is a simple test that can indicate the trend of corrosion, since it represent the current flux between anodic and cathodic areas on the metal surface.

Soil moisture below $20 \%$ indicates high resistivity values. Adding water, the resistivity decreases and the value remains constant after a specific value, considered as a minimum

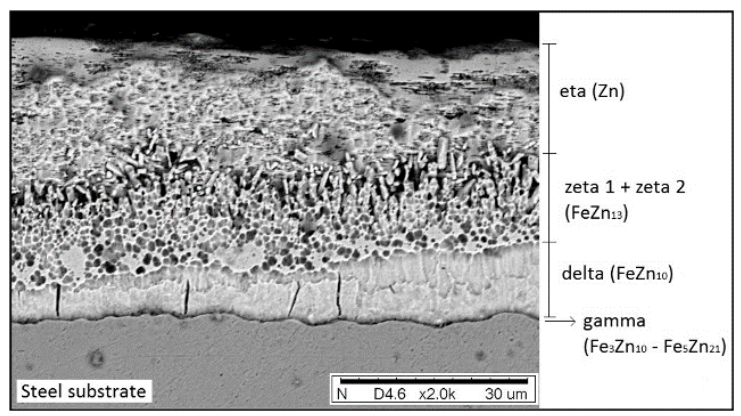

Figure 1. Microstructure of $\mathrm{Zn}$ coating (galvanized coupons). 
soil resistivity. According to specialized literature, a soil can be considered as a moderately corrosive medium if it presents some characteristics, including low resistivity, about $2,000 \mathrm{ohm} . \mathrm{cm}^{18}$. Considering this parameter, the clay soil used in this work can be consider a low aggressive medium, since the minimum resistivity is about 4,000 ohm.cm.

Table 1 presents the Steinrath and modified Steinrath Index classification based on chemical, physicochemical and microbiologic soil parameters. The soil $\mathrm{pH}$, about 5.3, indicates that zinc corrosion rates must be high ${ }^{1}$. However, the Starkey and Wight ${ }^{19}$ classification for redox potential suggests that the soil does not have corrosive behavior, which can be confirmed by the absence of chlorides and sulfates. $\mathrm{SRB}$ concentration was $10^{3}$ cells/g soil and their presence is a serious concern regarding corrosion occurrence ${ }^{2}$. Additionally, sulfide presence can be understood as a result of sulfate ion reduction by SRB present in the soil. The presence of sulfide, even in traces, is undesirable because the SRB can accelerate steel corrosion rate. However, depending on the sulfide product generated, it can decrease corrosion rates under specific conditions ${ }^{3,5}$.

According to Steinrath Index, the soil received the classification "low aggressive" and the total index was " -3 ". Considering the modified Steinrath index, that replaces redox potential by SRB count, the total index was "-7", also indicating a low aggressive soil. Although these indexes are important, electrochemical and gravimetric tests are necessary and essential to a careful analysis of the soil aggressiveness.

Electrochemical and gravimetric tests were conducted in both moisture conditions: high moisture (HM) and low moisture (LM). Soil moisture monitoring is shown in Figure 3, as well as the experimental device. At less deep level (LM) the soil moisture was maintained in values below $20 \%$, indicating higher resistivity values comparing to the deepest level (HM). In this way, it was possible to obtain results in different conditions of resistivity.

The corrosion potential was monitored during the immersion test. When steel coupons were immersed in soil, corrosion processes started to occur, which resulted in decrease of potential values and the stabilization after two days, as shown in Figure 4. Galvanized coupons present different behavior, since zinc maintain the potential in more cathodic value (more negative) than carbon steel coupon, regardless of the soil moisture content. The cathodic potential of galvanized steel is due to the zinc, the main element of the coating, which is more reactive. The corrosion potential reflects the trend to corrosion, since more negative values correspond to higher oxidation tendency. In fact, the lower corrosion potential of zinc makes it able to be used as a galvanic anode in cathodic protection systems. If damage occurs to the galvanized layer, the electrochemical cell

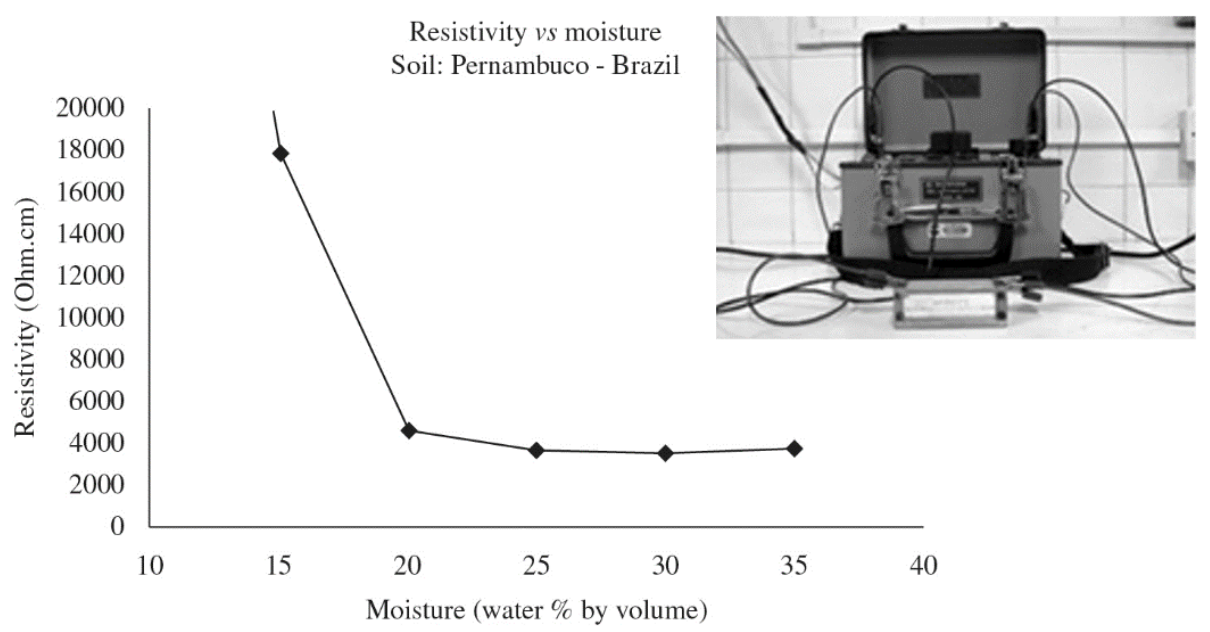

Figure 2. Profile of the electric resistivity $v s$ moisture content.

Table 1. Classification of corrosivity - Steinrath Index.

\begin{tabular}{cccc}
\hline Soil parameters & Value & Partial Steinrath Index & Partial modified Steinrath Index \\
\hline Resistivity $(\mathrm{Ohm} . \mathrm{cm})$ & 3710 & -1 & -1 \\
Moisture content $(\%)$ & 20 & 0 & 0 \\
$\mathrm{pH}$ & 5.3 & 0 & 0 \\
Redox Potential $\left(\mathrm{mV}_{\mathrm{Cu} / \mathrm{CuSO} 4}\right)$ & 827.4 & +2 & - \\
SRB concentration $(\mathrm{cells} / \mathrm{g}$ soil) & $1.1 \times 10^{3}$ & -- & -2 \\
Chloride content $(\mathrm{mg} / \mathrm{Kg})$ & - & 0 & -4 \\
Sulfide content $(\mathrm{mg} / \mathrm{Kg})$ & 0.83 & -4 & 0 \\
Sulfate content $(\mathrm{mg} / \mathrm{Kg})$ & - & 0 & -7 \\
Total aggressiveness index & & -3 & Low aggressive \\
Soil classification & & Low aggressive
\end{tabular}




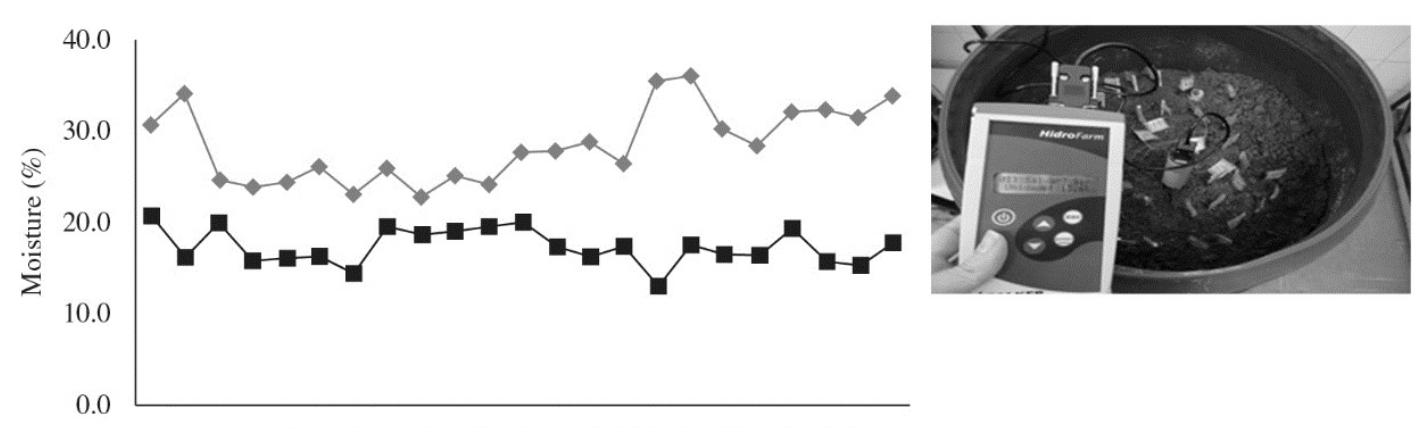

1223445567710111213181924252831333840485460

Time (days)

$\rightarrow \mathrm{HM} \rightarrow-\mathrm{LM}$

Figure 3. Soil moisture monitoring (HM: High moisture e LM: Low moisture).

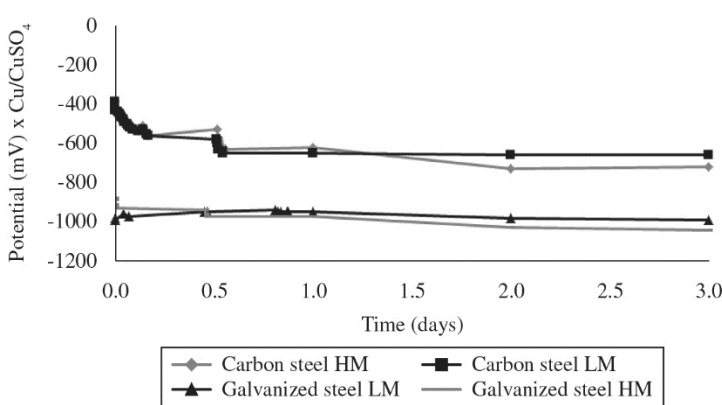

Figure 4. Corrosion potential monitoring (HM: High moisture e LM: Low moisture).

promotes the oxidation of the zinc. The zinc oxidation product is a thin, compact and adherent layer that protects the steel by two distinct mechanisms: cathodic protection and barrier protection ${ }^{2,15,16}$.

Electrochemical parameters can be obtained from polarization curves (Figure 5) considering Tafel slope, as shown in Table 2. There is no passivation domain in the anodic branch for steel coupons and this behavior indicates that the preferential corrosion morfology is uniform and localized corrosion, as pitting for example, is not expected.

The soil resistivity influences the corrosion current density, confirming that the lower the resistivity, the higher the current density and the tendency to corrosion. The polarization curves show higher density values in high moisture condition. According to Tafel slope (Table 2 and Figure 5), galvanized steel presents higher current densities than carbon steel in both moisture conditions. The anodic polarization curve represents oxidation reactions on the surface and the current density observed in galvanized coupons reflect the tendency of zinc oxidation, as previously discussed.

Polarization test is a useful tool to evaluate corrosion processes but an important factor should be pointed out: it is an accelerated test and some reactions could not be observed in a short period of exposure to an environment. For instance, the formation of oxide layers on steel coupons in accelerated tests could differ from those obtained in longer periods of exposure, reflecting in different corrosion rates

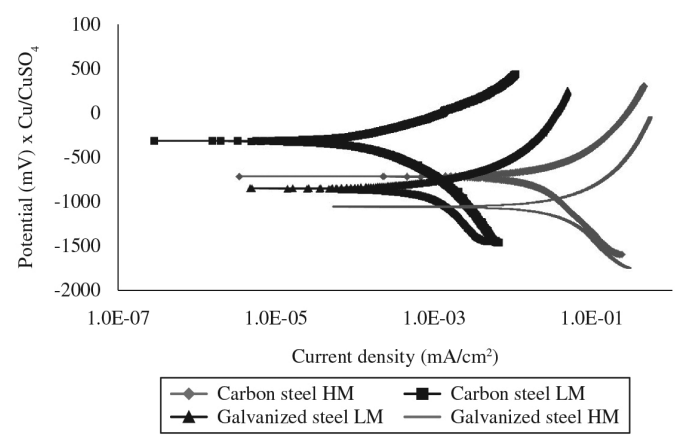

Figure 5. Polarization curves in soil with different moistures.

when considering Tafel slope extrapolation or gravimetric methods (Table 3).

Figure 6 and Table 3 show the corrosion rates obtained by gravimetric tests, using four coupons per measurement point. As usual, the corrosion rate of steel coupons, without coatings, decreases due to films formed on the metallic surface. In the beginning of the test, the metal is clean and reactions are favored. This behavior is not evident for galvanized steel, which may be attributed to the previously coating layer applied to the steel.

Considering the gravimetric test, the corrosion rates of galvanized steel buried in higher moisture (lower resistivity) were higher than the values obtained in lower moisture, according the expected values. According to NACE RP-077514[14], HM and LM soil were considered as moderate and low, respectively. These values point out a trend to corrosion in higher moistures, in accordance with the polarization curves. The moderate corrosion rates in $\mathrm{HM}$ are not in agreement with the "low aggressiveness" classification supplied by Steinrath Index. While relevant, the predictions supplied by index should not be a unique criterion when assessing soil aggressiveness.

In higher moisture content, i.e. more aggressive soil, the corrosion rate of galvanized steel increases. The corrosion current density obtained from polarization curves corroborates with gravimetric tests. The corrosion of metallic alloys, as well as the dissolution of soil compounds, should be favored by higher water content. However, in 
Table 2. Electrochemical parameters obtained by Tafel slope to galvanized steel and carbon steel buried in soil. (HM: High moisture e LM: Low moisture).

\begin{tabular}{cccc}
\hline Material & Moisture Level & $\begin{array}{c}\text { Ecorr } \\
\left(\mathbf{m} \mathbf{V}_{\mathrm{Cu} / \mathrm{Cus} 4}\right)\end{array}$ & $\begin{array}{c}\text { Corrosion current density } \\
\left(\boldsymbol{\mu} \mathbf{A} / \mathbf{c m}^{2}\right)\end{array}$ \\
\hline Galvanized steel & LM & -840.8 & 0.00477 \\
& HM & -1047.0 & 0.05270 \\
Carbon steel & LM & -305.7 & 0.00029 \\
& HM & -705.8 & 0.00346 \\
\hline
\end{tabular}

Table 3. Corrosion rates obtained by the gravimetric method to galvanized steel and carbon steel. (HM: High moisture e LM: Low moisture).

\begin{tabular}{ccccc}
\hline \multicolumn{5}{c}{ Corrosion rate $(\mathbf{m m} / \mathbf{y e a r})$} \\
\hline Material & $\mathbf{1 5}$ days & $\mathbf{3 0}$ days & $\mathbf{4 5}$ days & $\mathbf{6 0}$ days \\
\hline Galvanized Steel - LM & $0.0095 \pm 0.0009$ & $0.0051 \pm 0.0008$ & $0.0119 \pm 0.0013$ & $0.0034 \pm 0.0003$ \\
Galvanized Steel - HM & $0.0487 \pm 0.0011$ & $0.0434 \pm 0.0017$ & $0.0441 \pm 0.0020$ & $0.0393 \pm 0.0008$ \\
Carbon Steel - LM & $0.2182 \pm 0.0021$ & $0.1911 \pm 0.0017$ & $0.1626 \pm 0.0012$ & $0.1205 \pm 0.0015$ \\
Carbon Steel - HM & $0.0863 \pm 0.0013$ & $0.0602 \pm 0.0006$ & $0.0533 \pm 0.0006$ & $0.0419 \pm 0.0007$ \\
\hline
\end{tabular}

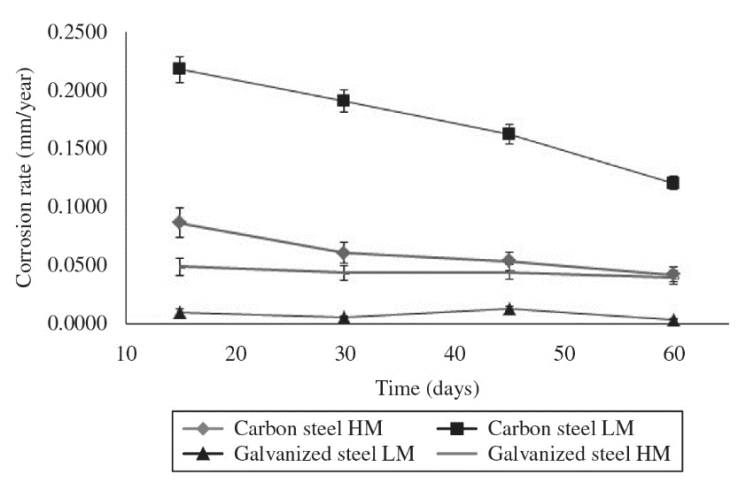

Figure 6. Corrosion rates obtained by the gravimetric method (HM: High moisture e LM: Low moisture).

this work, the corrosion rates of carbon steel coupons were lower than the results obtained in higher moisture content (lower resistivity). The formation of corrosion products on the metallic surface, which depends on the soil soluble compounds present, can be responsible to this unexpected result. In previous work ${ }^{20-22}$, the lower corrosion rate in higher moisture condition was also observed due to sulfur compounds deposited on the metallic surface, which reduced the corrosion rate.

\section{References}

1. American Galvanizers Association. Performance of hot-dip galvanized steel products: in the atmosphere, soil, water, concrete, and more. Colorado: American Galvanizers Association; 2010. Available from: <http://www.researchgate.net/publictopics. PublicPostFileLoader.html?id=54ab9eb2d3df3e7a548b45a0 $\& k e y=0 f d 74 a 68-9 f d a-4 e f c-9 a 07-725267 f a 736 d>$. Access in: $15 / 01 / 2014$.

2. Gentil V. Corrosão. 6th ed. Rio de Janeiro: Livros Técnicos e Científicos; 2011. p. 57-72.

3. Padilla V, Ghods P and Alfantazi A. Effect of de-icing salts on the corrosion performance of galvanized steel in sulphate contaminated soil. Construction \& Building Materials. 2013; 40(1):908-918. http://dx.doi.org/10.1016/j.conbuildmat.2012.09.077.

\section{Conclusions}

- Although the literature may indicate the degree of corrosiveness based on resistivity and other parameters, gravimetric tests must be carried out to determine the corrosion rate in real time. In this study, the corrosion rates observed in lower soil moisture did not reflect the aggressiveness degree indicated through specific index mentioned in the literature.

- Hot dip galvanizing reduces the corrosion rates of carbon steel buried in soil, especially in low moisture content. Corrosion rates of galvanized steel buried in higher moisture (lower resistivity) were higher than the values obtained in lower moisture. According to literature, the values were considered as moderate and low, respectively.

- Steel polarization curves show higher current density values in higher moisture condition, which indicate the increase of corrosion rates related to soil moisture. However, gravimetric tests indicate lower corrosion rate of steel in higher moisture. This unexpected result, also found in previous works, can be explained by corrosion products formed on the surface, which depend on the soil soluble compounds present.

4. Silva JM and Brasil SL. Critério de avaliação da corrosividade de solos baseado na sobretenção de hidrogênio. Corrosão $e$ Protecção de Materiais. 2010; 29(1):19-25.

5. Trabanelli G, Zucchi F and Arpaia M. Methods of determination of soil corrosiveness with respect to metallic structures. Chinica Pura ed Applicata. 1972; 4(3):43-59.

6. Associação Brasileira de Normas Técnicas - ABNT. NBR 7414: zincagem por imersão a quente. Rio de Janeiro; 2009.

7. Vogel A. Química analítica quantitativa. 5th ed. São Paulo: Mestre Jou; 1981.

8. Grupo Coordenador de Operação Interligada / Subcomitê de Manutenção - GCOI/SCM. Obtenção da curva característica de resistividade em relação à percentagem de água em solos. III Encontro Técnico de Corrosão e Proteção. Recomendação 
técnica; 1995; Rio de Janeiro, Brasil. Brasil: Eletrobrás; 1995. p. 03-05.

9. Costanzo FE and McVey RE. Development of the Redox Probe Field Technique. Corrosion. 1958; 14(1):268-272.

10. Empresa Brasileira de Pesquisa Agropecuária - EMBRAPA. Parte II - Análises químicas. In: Empresa Brasileira de Pesquisa Agropecuária - EMBRAPA. Manual de métodos de análise de solo. 2nd ed. Rio de Janeiro: EMBRAPA-CNPS, 1997. p. 81-83.

11. Postgate JR. The sulphate-reducing bacteria. 2nd ed. Cambridge: Cambridge University Press; 1984. p. 43-44.

12. American Society for Testing and Materials - ASTM. G1 03: Standard practice for preparing, cleaning and evaluation corrosion test specimens. ASTM; 2003.

13. National Association of Corrosion Engineers - NACE. RP 0775 : Standard recommended practice - preparation, installation, analysis and interpretation of corrosion coupons oilfield operations. NACE; 2013.

14. American Society for Testing and Materials - ASTM. G9690: Standard guide for online monitoring of corrosion in plant equipment (Electrical and Electrochemical Methods). ASTM; 2013.

15. Marder AR. The metallurgy of zinc-coated steel. Progress in Materials Science. 2000; 45(3):191-271. http://dx.doi. org/10.1016/S0079-6425(98)00006-1.
16. Bicao P, Jianhua W, Xuping S, Zhi L and Fucheng Y. Effects of zinc bath temperature on the coatings of hot-dip galvanizing. Surface and Coatings Technology. 2008; 202(9):1785-1788. http://dx.doi.org/10.1016/j.surfcoat.2007.07.044.

17. Associação Brasileira de Normas Técnicas - ABNT. NBR 6323: galvanização de produtos de aço ou ferro fundido - especificação. Rio de Janeiro; 2007.

18. National Association of Corrosion Engineers - NACE. NACE International Publication 05101. State-of-the-art survey on corrosion of steel piling in soils. NACE; 2001

19. Starkey RL and Wright KM. Anaerobic corrosion of irons in soils. Nova York: American Gas Association; 1945.

20. Freitas DS, Brasil SLDC, Coelho FP, Oliver JHL, Araujo FVL and Lima LG. Ensaios para avaliação da corrosividade de solos. In: Anais do INTERCORR 2010 - 3rd International Corrosion Meeting; 2010; Fortaleza, Brasil. Natal; 2010.

21. Loureiro A, Brasil S and Yokoyama L. Estudo da corrosividade de solo contaminado por substâncias químicas através de ensaios de perda de massa e Índice de Steinrath. Corrosão e Protecção de Materiais. 2007; 26(4):113-121.

22. Brasil SLDC, Freitas DS, Coelho JFP, Telles JCF, Santiago JAF and Oliver JHL. Methodology for evaluation of soil corrosiveness in buried pipelines for different regions of Rio de Janeiro. In: EUROCORR 2010 - The European Corrosion Congress; 2010; Moscow, Russia. Moscow; 2010. 